\title{
Granulated polyamide as external marker to estimate total faecal excretion of grazing cattle in extensive management systems
}

\author{
BY FRIEDRICH MAHLER*, EVA SCHLECHT $\dagger$, MAMADOU SANGARE $\dagger$ \\ AND KLAUS BECKER \\ Institute for Animal Production in the Tropics and Subtropics, University of Hohenheim, \\ D-70593 Stuttgart, Germany
}

(Received 20 September 1996 - Revised 7 February 1997 - Accepted 27 February 1997)

\begin{abstract}
Granulated polyamide (PA) was tested for use as an external marker to estimate faecal DM (FDM) excretion of Zebu cattle (Bos indicus). The study was conducted in Mali, using seven and eighteen animals respectively in four field trials and six indoor experiments. Cattle ate fresh or dry pasture vegetation and half the animals were additionally supplemented with crop byproducts. Gelatine capsules containing 35,40 or $45 \mathrm{~g}$ PA were administered orally at $12 \mathrm{~h}$ intervals. Estimates of FDM were based on the average marker concentration in faeces and were correlated with the actual excretion measured by total faecal collection. The pre-measurement period required to establish equilibrium for regular marker dosing was determined at $4 \mathrm{~d}$. Except for diets with a $\mathrm{N}$ content of less than $9.26 \mathrm{~g} / \mathrm{kg}$ organic matter, marker recovery averaged 98.1 (SE 0.93 ) \% ( $n$ 62), and was not influenced by diet composition and the quantity of feed ingested $(P>0.05)$. Estimates of FDM based on average $P A$ concentrations in faecal samples were correlated to the actual excretion with $r 0.98(n$ $62 ; P \leq 0.001)$. Since the PA concentration in individual faecal grab-samples is not correlated with either sample mass or sampling time, accurate estimates of FDM require a grab-sampling schedule that covers the $24 \mathrm{~h}$ day. However, estimates of FDM were found to be acceptable if calculations are based on the average PA concentration in the sub-total of samples collected during the day or during night respectively $(r 0.95, n 29 ; P \leq 0.001$ in both cases). It is concluded that the use of PA marker is a simple and inexpensive method resulting in reliable estimates of FDM. Since sophisticated analytical procedures are not required to recover PA in faecal samples, the marker is particularly suitable for application in extensive grazing systems and in studies conducted in less-developed countries.
\end{abstract}

Faeces: Polyamide marker: Extensive grazing systems: Cattle

A reliable determination of feed intake is a prerequisite to study the nutritional status of cattle grazing natural pastures. Most commonly, estimates of intake are based on the determination of in vitro ingesta digestibility and faecal output (Mayes et al. 1995). Although faeces can be collected quantitatively using collection bags, the application of faecal markers is an advantage under field conditions because this approach has very little influence on the animal's grazing behaviour. It is easily applicable to relatively large numbers of animals and is suitable for studies on females (Reid et al. 1952; Kotb \& Luckey, 1972; Langlands, 1974). Using markers, the accuracy of the estimated faecal excretion depends greatly on a representative collection of faecal samples (Whittington \& Hansen, 1985), especially when there are distinct variations in the animal's diurnal patterns

* Present address: International Crops Research Institute for the Semi-Arid Tropics, BP 12404 Niamey, Niger.

$\uparrow$ Present address: International Livestock Research Institute, BP 12404 Niamey, Niger. 
of feed intake and when the pasture shows heterogeneous species distribution or contains both herbaceous and ligneous vegetation.

The different types of markers as well as the principles, advantages and problems of their application have been thoroughly discussed (Kotb \& Luckey, 1972; Langlands, 1974; Cordova et al. 1978; Holechek et al. 1982; Meuret et al. 1985; Cochran et al. 1986, 1988; Mayes et al. 1995). However, for most markers the sophisticated analytical procedures required for their measurement are often not applicable in less-developed countries (DickoTouré, 1980). Small plastic particles that have been used frequently for studies on ruminal and post-ruminal rates of particulate passage have the advantage that only simple laboratory equipment is necessary to measure them gravimetrically in faecal samples. Plastic particles of 1-2 mm diameter and up to $4 \mathrm{~mm}$ length and having a specific gravity of 1.10-1.28 showed maximal gastrointestinal rates of passage in cattle and small ruminants (King \& Moore, 1957; Campling \& Freer, 1962; Katoh et al. 1988; Murphy et al. 1989; Prigge et al. 1990; Welch, 1990). The rapid rate of passage combined with easy recovery suggests that small plastic particles should be a suitable marker substance for the quantification of faecal excretion. The present study, therefore, investigates the potential of small polyamide (PA) particles for use as an external faecal marker to accurately estimate DM excretion of free-ranging cattle. Easy handling of the marker and quick and easy analysis of faecal samples were considered to be important factors when only minimal laboratory facilities are available.

\section{MATERIALS AND METHODS}

The marker tested was granulated PA (PA- $6^{\circledR}$; Friesetta GmbH Kunststoffwerk, D-79677 Schoenau, Germany), a hard, transparent and physiologically-inert plastic. The particles of $2-3 \mathrm{~mm}$ diameter have a specific gravity of $1 \cdot 12-1 \cdot 15$ and a ball indentation hardness of $50-80 \mathrm{~N} / \mathrm{mm}^{2}$. Studies on the suitability of PA as an external marker to estimate total faecal excretion of grazing cattle were conducted at the Station des Recherches Zootechniques du Sahel at Niono, Mali, from March 1989 to June 1992. The site is in the southern Sahelian zone and has a semi-arid climate with a single rainy season from June to October. Long-term annual precipitation averages $487 \mathrm{~mm}$ (years 1958-1988). Cattle production mainly depends on feed supply from natural pastures and harvested millet (Pennisetum glaucum) fields. During the dry season, animals are occasionally supplemented with locally-available crop byproducts.

The rate of passage of PA particles was studied in an initial experiment with five housed Zebu oxen (Bos indicus). Four field trials were carried out on a total of seven oesophageally-fistulated oxen. Additionally, five indoor experiments were conducted on a total of eighteen oxen to determine the influence of ingesta quantity and quality on marker recovery.

\section{Patterns of marker excretion}

To determine the rate of passage and the recovery of the marker, an initial trial was carried out on five animals (live weight 293 (SD 43.6) kg) kept indoors. The diet consisted of bush hay harvested on natural pasture, cowpea (Vigna unguiculata) hay and wheat meal offered as one ration in the proportions 1.0:1.0:0.5 (on fresh mass basis; average DM content $920 \mathrm{~g} / \mathrm{kg}$ ) and was distributed at levels of $29.6,34.1,43.5,50.1$ and $92.1 \mathrm{~g} \mathrm{DM} / \mathrm{kg}$ live weight $^{0.75}$ per $\mathrm{d}$ ( $n 1$ per level). Each animal was offered its ration in two equal portions at 07.00 and 17.00 hours. After a $10 \mathrm{~d}$ adaptation period, the animals received a single dose of $225 \mathrm{~g}$ PA. As in all trials, gelatine capsules $(30 \mathrm{~mm} \times 95 \mathrm{~mm})$ were filled with $40-45 \mathrm{~g}$ 
marker particles and administered orally with the help of an applicator. Due to difficulties in handling, the animal which was offered the highest amount of feed received only $175 \mathrm{~g}$ PA. Starting at the moment of marker dosing, faecal excretion was measured during six consecutive days with every defaecation collected immediately in a plastic bowl held behind the animal. All defaecations were dried individually and analysed separately as described later (p. 791). Marker concentrations in faecal samples of the five animals were listed in chronological order. Marker excretion patterns were calculated as the moving average of the five animals, using overlapping windows of twenty-one contiguous data points each.

\section{Field trials}

Four trials (F1-F4) were carried out during the second half of the dry season when cattle were grazing on communal pastures and harvested millet fields. Three of the seven animals relied exclusively on grazed herbage, while four were additionally supplemented daily with $0.5 \mathrm{~kg}$ rice feed meal and $1 \mathrm{~kg}$ cowpea hay (on a fresh matter basis). Animals were herded from 07.00 to 18.30 hours and corralled overnight. Water was provided during a $1-2 \mathrm{~h}$ rest at approximately 12.00 hours. Supplements were given individually. Cowpea hay was offered overnight and rice feed meal was fed in the morning before the animal left the corral.

The quality of the diet selected on pasture was determined from samples of oesophageal extrusa collected during five consecutive days (Harniss et al. 1975). Twice in the morning and twice in the afternoon extrusa was collected from an animal, such that samples from supplemented and unsupplemented animals were collected simultaneously in trials F1 and F2. Each animal was sampled only once daily and the sampling time was limited to $30 \mathrm{~min}$. The order in which the animals were sampled was determined by a Latin square design to account for interactions between animal and sampling times. Approximately $700 \mathrm{~g}$ of extrusa fresh matter were collected into water-tight bags (Little, 1972) and kept on ice until drying. To avoid browning effects, samples were dried to constant mass at $49^{\circ}$ (Scales et al. 1974). They were ground through a $1 \mathrm{~mm}$ sieve and stored air-tight.

In all trials, the marker was administered twice daily, at 06.30 and 18.30 hours, at a rate of 35 or $70 \mathrm{~g}$ PA per application (Table 1). Continuous marker dosing started $4 \mathrm{~d}$ before the 5 to $10 \mathrm{~d}$ measurement period. Total faecal excretion was measured using faecal collection bags, with the animals being adapted to the bags $4 \mathrm{~d}$ before the measurement period. For each animal, faeces were pooled daily and duplicate sub-samples were taken to determine their marker content as described later (p. 791). In trials F2 and F4, total collection was combined with rectal grab-sampling of faeces at intervals of 5 or $10 \mathrm{~h}$ during five consecutive days. In trial F1, faeces were also taken during three fixed intervals of $2 \mathrm{~h}$ in the morning, at $\mathbf{1 2 . 0 0}$ hours and in the evening.

Forage intake on pasture was calculated from the quantity of faeces excreted and the digestibility of the selected diet.

\section{Indoor experiments}

To examine the influence of ingesta quantity and quality on the recovery of the PA marker, five indoor experiments (C1-C5) were conducted on a total of eighteen animals. Animals nos. 1-6 were used in trial $\mathrm{C} 1$, animals 7-18 participated in trials $\mathrm{C} 2-\mathrm{C} 5$ and were allocated at random to the different treatments in each experiment. In all trials, water was provided ad libitum and mineral licks were constantly available. The ration was based on 


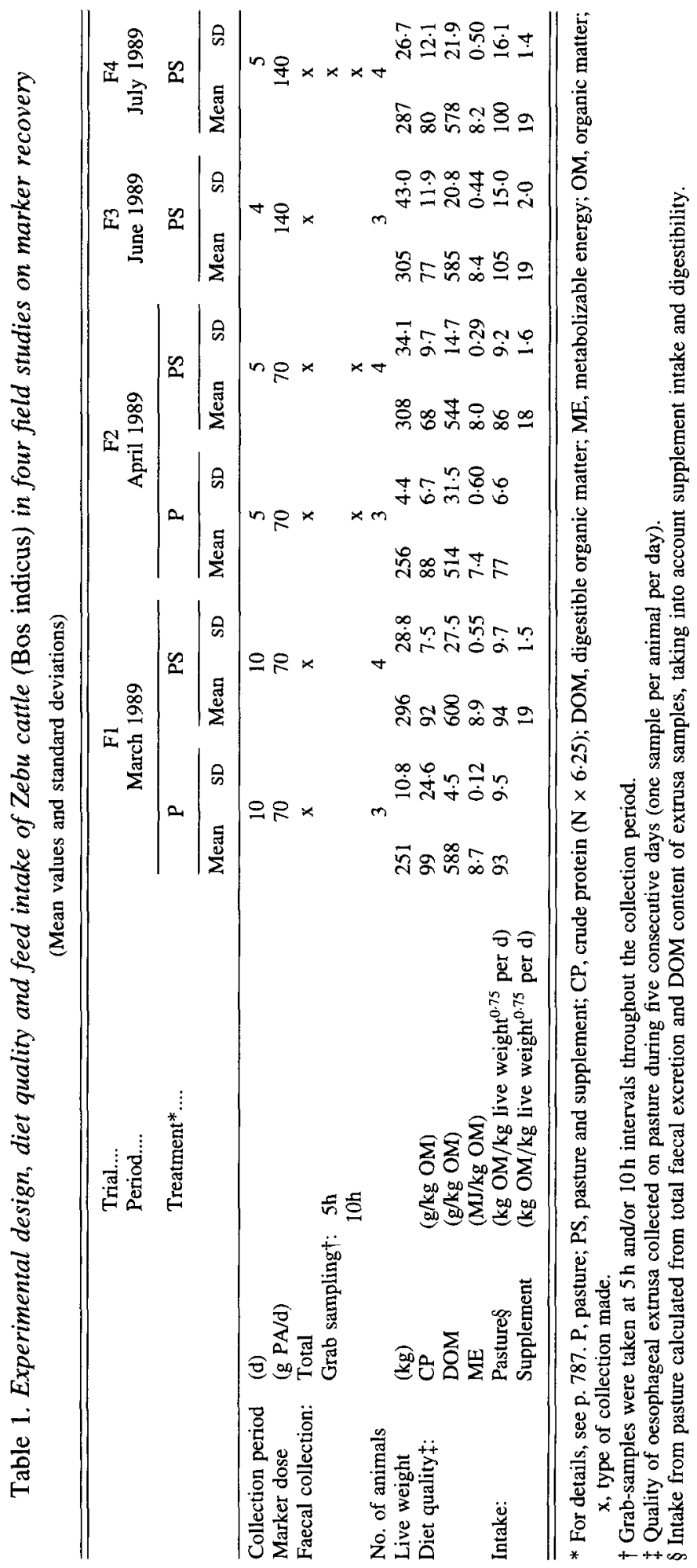


Table 2. Feed quality in indoor experiments on marker recovery in Zebu cattle (Bos indicus) (Values are averages)

\begin{tabular}{|c|c|c|c|c|c|c|c|c|}
\hline Trial & Feed & Type of feed & $n$ & $\begin{array}{c}\text { DM } \\
(\mathrm{g} / \mathrm{kg} \mathrm{FM})\end{array}$ & $\begin{array}{c}\text { OM } \\
\text { (g/kg DM) }\end{array}$ & $\begin{array}{c}\mathrm{CP} \\
(\mathrm{g} / \mathrm{kg} \mathrm{OM})\end{array}$ & $\begin{array}{c}\text { DOM } \\
(\mathrm{g} / \mathrm{kg} \mathrm{OM})\end{array}$ & $\begin{array}{c}\mathrm{ME} \\
(\mathrm{MJ} / \mathrm{kg} \mathrm{OM})\end{array}$ \\
\hline \multirow[t]{2}{*}{$\mathrm{C} 1$} & Rice straw & B & 5 & 950 & 853 & 19 & 550 & $7 \cdot 3$ \\
\hline & Cowpea hay & $\mathbf{S}$ & 8 & 940 & 895 & 124 & 690 & 9.4 \\
\hline \multirow[t]{2}{*}{$\mathrm{C} 2$} & Rice straw & B & 8 & 914 & 851 & 28 & 482 & $6 \cdot 9$ \\
\hline & Cowpea hay & $\mathbf{S}$ & 5 & 890 & 906 & 189 & 711 & $10 \cdot 8$ \\
\hline \multirow[t]{3}{*}{ C3 } & Bush hay & B & 7 & 920 & 931 & 29 & 441 & 5.9 \\
\hline & Rice feed meal & $\mathbf{S}_{1} \dagger$ & 5 & 928 & 898 & 128 & 590 & 11.0 \\
\hline & Cottonseed expeller & $\mathrm{S}_{2}^{\dagger}$ & 5 & 929 & 940 & 293 & 613 & 9.9 \\
\hline \multirow[t]{2}{*}{$\mathrm{C} 4$} & Green pasture veg & B & 10 & 319 & 888 & 124 & 617 & 9.5 \\
\hline & Rice feed meal & $S$ & 5 & 925 & 851 & 105 & 688 & $12 \cdot 4$ \\
\hline \multirow[t]{2}{*}{$\mathrm{C} 5$} & Green pasture veg & $\mathrm{B}$ & 9 & 365 & 918 & 100 & 583 & 8.7 \\
\hline & Rice feed meal & $\mathbf{S}$ & 5 & 920 & 869 & 105 & 600 & 11.0 \\
\hline
\end{tabular}

B, basic feed; S, supplement; DM, dry matter; FM, fresh matter; OM, organic matter; $\mathrm{CP}$, crude protein $(\mathrm{N} \times 6.25)$; DOM, digestible organic matter; ME, metabolizable energy; veg, vegetation. $\dagger S_{1}-S_{2} 1: 1, w / w$.

rice straw in trials $\mathrm{C} 1$ and $\mathrm{C} 2$. In the other trials, the basal diet consisted of either bush hay (C3) or green herbaceous vegetation $(\mathrm{C} 4, \mathrm{C5})$ harvested on natural pasture. Rations were supplemented with cottonseed expeller, rice feed meal or cowpea hay. The quality of the distributed feeds is shown in Table 2.

Feeding levels were calculated as multiples of the digestible organic matter (DOM) requirement for maintenance $\left(33 \mathrm{~g} \mathrm{DOM} / \mathrm{kg}\right.$ live weight ${ }^{0.95}$ per d; Agricultural Research Council, 1980). Diets were classified as low intake (L) corresponding to maintenance, moderate intake $(\mathrm{M})$ corresponding to $1.3 \times$ maintenance and high intake $(\mathrm{H})$ corresponding to $1.6 \times$ maintenance; supplement treatments were LS, MS and HS respectively. Collection periods, marker doses, feeding levels and quantities of feed distributed and consumed are shown in Table 3.

The feed was offered individually in two equal meals at 07.00 and 17.00 hours daily. Green feed $(\mathrm{C} 4, \mathrm{C} 5)$ and bush hay (C3) were always harvested $18 \mathrm{~h}$ before feeding. The hay was stored in sacks, and the green feed was kept in loose stacks on a concrete floor, shaded by a tin roof. In this way a relatively constant DM content for the green feed on offer was maintained.

All trials were preceded by an adaptation period of $10 \mathrm{~d}$. During the measurement period, samples of feed on offer were taken daily. Food refusals were weighed once daily and samples kept for analysis. To be congruous with the field experiments, the marker was administered at 06.30 and 18.30 hours, before the start of the morning meal and towards the end of the evening meal. PA was administered at a rate of $35 \mathrm{~g}(\mathrm{Cl}), 40 \mathrm{~g}(\mathrm{C} 4, \mathrm{C} 3$ and $\mathrm{C} 5$, treatments $\mathrm{L})$ or $45 \mathrm{~g}(\mathrm{C} 2, \mathrm{C} 3$ treatment $\mathrm{M}, \mathrm{C} 5$ treatment $\mathrm{H})$ per application. Continuous marker dosing started $4 \mathrm{~d}$ before the measurement period. During the measurement period, each defaecation was collected individually in a plastic bowl held behind the excreting animal (C1-C5). Faeces collected in this way were weighed and pooled for each $24 \mathrm{~h}$ period. In addition, grab-sampling of faeces took place every $7 \mathrm{~h}$ throughout the measurement period in trials C3, C4 and C5. Marker concentration in faeces was determined in aliquot samples which were sub-sampled daily from the $24 \mathrm{~h}$ pool of total excreta of individual animals $(\mathrm{C} 1, \mathrm{C} 2, \mathrm{C} 3)$ or in rectal grab-samples $(\mathrm{C} 3, \mathrm{C} 4, \mathrm{C5})$. In 


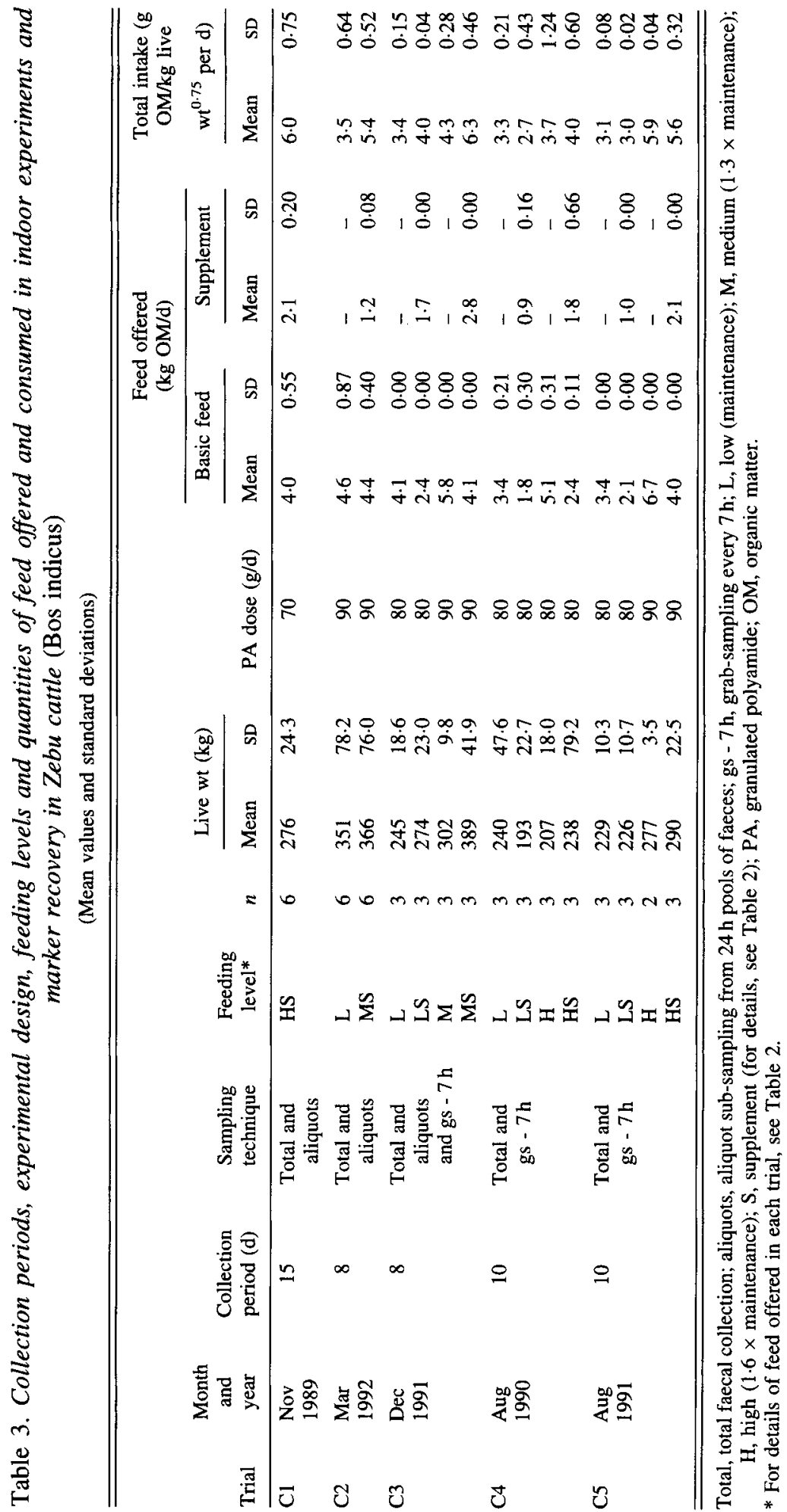


trial C5, not only grab-samples but every defaecation excreted between 07.00 and 18.00 hours was analysed individually for its PA content.

\section{Analyses of oesophageal extrusa, feed and faecal samples}

Residual moisture, crude ash, and crude protein $(\mathrm{N} \times 6.25)$ contents of roughage feeds, supplements, and oesophageal extrusa were determined according to standard procedures (Naumann et al. 1983). DOM and metabolizable energy content were derived from the gas production of approximately $200 \mathrm{mg}$ air-dry sample incubated with rumen contents in vitro for $24 \mathrm{~h}$ (Menke et al. 1979).

The processing of faecal samples was identical for the initial, field and indoor experiments. In trials $\mathrm{Cl}-\mathrm{C} 5$, the average air-dry matter content of a number of faecal samples was determined during the adaptation period and the amount of water needed to dilute faeces to a moisture content of $800-900 \mathrm{~g} / \mathrm{kg}$ was calculated. In order to sub-sample mass aliquots from the $24 \mathrm{~h}$ pools of total excreta during measurement periods, the pooled faeces were weighed to $\pm 0.2 \mathrm{~g}$, placed in a plastic container and diluted with water. The moisture content of the diluted faeces was determined at $820-850 \mathrm{~g} / \mathrm{kg}$. Immediately after thorough mixing of the diluted faeces by manual stirring for $5 \mathrm{~min}$, two aliquot sub-samples of $10 \mathrm{~g} / \mathrm{kg}$ total mass of the homogenized pool were taken.

Grab samples were treated individually. After determination of fresh sample mass, aliquot sub-samples and grab-samples were dried to constant mass at ambient temperatures $\left(29-35^{\circ}\right)$, weighed again and ground in a household blender without damage to the polyamide particles. The marker was recovered from the ground samples by sifting $(1 \mathrm{~mm}$ sieve). If faecal particles rested on the sieve, they were removed by hand. The quantity of marker recovered was weighed to the nearest milligram. To determine the influence of the grinding procedure on PA recovery, defined amounts of PA $(20,25,30,35,40,45 \mathrm{~g}$, replicated three times each) were added to a fixed quantity of fresh faeces (equivalent of $1 \mathrm{~kg}$ faecal DM (FDM)). On average, 100.7 (SE 0.03$) \%(n 18)$ of air-dry PA added to fresh faeces was recovered after the drying, grinding and sieving process. The slight increase in PA mass was due to dust particles sticking to the grains. Although washing and drying of the particles brought recovery to $100.6 \%$, those procedures increase the risk of particle losses. It was decided, therefore, not to wash the recovered PA grains but to accept the small bias originating from dust adhesion. Marker content of samples was expressed as $\mathrm{g}$ PA/kg FDM. From the PA concentration in individual grab-samples and in aliquot subsamples, respectively, the marker concentration for the whole sampling period was calculated as an unweighted average value for each animal. Based on the observation that extremely high or low marker concentrations mainly occur in very small grab-samples, it was decided to apply the following corrections: grab-samples of less than $10 \mathrm{~g} \mathrm{DM}$, grabsamples without any PA particles and grab-samples where the PA concentration differed by more than 3 SD from the mean were excluded. Marker recovery was calculated from mean daily marker excretion in faeces divided by the average daily marker intake during the collection period, where faecal marker excretion (g PA/d) was obtained from average daily FDM excretion (g FDM/d, determined by total collections) multiplied by the average marker concentration (g PA/kg FDM) in faecal grab-samples (F2, F4, C3, C4, C5) or in aliquot sub-samples (F1, F3, C1, C2). To estimate average FDM from marker application, the amount of PA administered daily (g PA/d) was divided by the average PA concentration (g PA/kg FDM) of aliquot sub-samples or grab-samples respectively. 


\section{Data analysis}

To assess the influence of supplementation, marker dose, and sampling procedure on marker recovery in field experiments, factorial ANOVA was performed using the general linear model procedure (GLM) provided by the Statistical Analysis Systems (1989) software package. The 'nested' classification was used to account for correlation between measurements from the same animal (animal nested in supplement treatment; Littell et al. 1991). For the comparison of marker recoveries within and between the five indoor experiments, the independent variables 'type of feed' and 'feeding level' were also included in the model. Multiple comparisons of means were computed by 'contrast' statements. Simple linear regression analysis was carried out to determine the correlation between actual faecal excretion and estimated values across experiments. The effects of diet digestibility, $\mathbf{N}$ content and organic matter intake on marker recovery were determined using multiple linear regression analysis. The correlation between dietary $\mathrm{N}$ content and PA recovery was further analysed using a non-linear segmented regression consisting of two linear sections with one joint point (Statistical Analysis Systems, 1989).

\section{RESULTS}

\section{Marker kinetics}

The first marker particles appeared in the faeces 13.0 (SE 0.63) h $(n$ 5) after administration of a single pulse dose. Peak concentration was reached 30.6 (SE 2.11) h ( $n$ 5) after marker application, and after $134 \mathrm{~h} 98.5(\mathrm{SE} 1.30) \%(n$ 5) of the administered marker dose was excreted. The marker excretion expected for continuous dosing was determined mathematically from the course of PA concentration in faeces following pulse dose application by superimposing the decay curve at intervals of $12 \mathrm{~h}$. Fig. 1 indicates that with marker dosing at regular intervals, marker concentration in faeces oscillates closely around a plateau value after $102 \mathrm{~h}$ following first marker application. The derived result was confirmed by trial F1, where PA recovery reached a plateau value on average $4 \mathrm{~d}$ after the start of continuous marker application (Fig. 2). The required period for marker concentrations to reach equilibrium before the collection of faecal samples was therefore fixed at $4 \mathrm{~d}$ and was adhered to in further trials.

\section{Marker recovery}

Marker recovery determined by grab-sampling was in accordance with the recovery obtained from total faecal collection followed by aliquot sub-sampling $(P>0.05$, trials $\mathrm{F} 2$, F4, C3). In the field, marker recovery did not differ significantly between unsupplemented and supplemented animals (Table 4). The amount of marker administered daily has no influence on marker recovery. With $70 \mathrm{~g} \mathrm{PA} / \mathrm{d}$ being administered to unsupplemented and supplemented animals grazing natural pasture $(\mathrm{F} 1, \mathrm{~F} 2)$, recovery averaged 99.0 (SE 3.04) \% ( $n$ 6) and 97.2 (SE 2.81$) \%(n$ ) respectively, and amounted to 96.9 (SE 1.83) \% (n 7) when supplemented animals received a dose of $140 \mathrm{~g} \mathrm{PA} / \mathrm{d}(P>0.05)$.

Taking rectal grab-samples at $10 \mathrm{~h}$ intervals during five consecutive days (F2), marker recovery was 104.2 (SE 4.05) \% (n 3) and 97.1 (SE 4.22) \% ( $n$ 4) for unsupplemented and supplemented animals respectively $(P>0.05)$, and the estimated quantity of faeces was 96.4 (SE 3.83) \% (n 3) and 103.8 (SE 4.72) \% ( $n$ 4) of the amount actually excreted. Grabsampling at intervals of $5 \mathrm{~h}$ within the measurement period of $5 \mathrm{~d}(\mathrm{~F} 4)$ increased the number of grab-samples from twelve to twenty-four. Marker recovery was determined for 


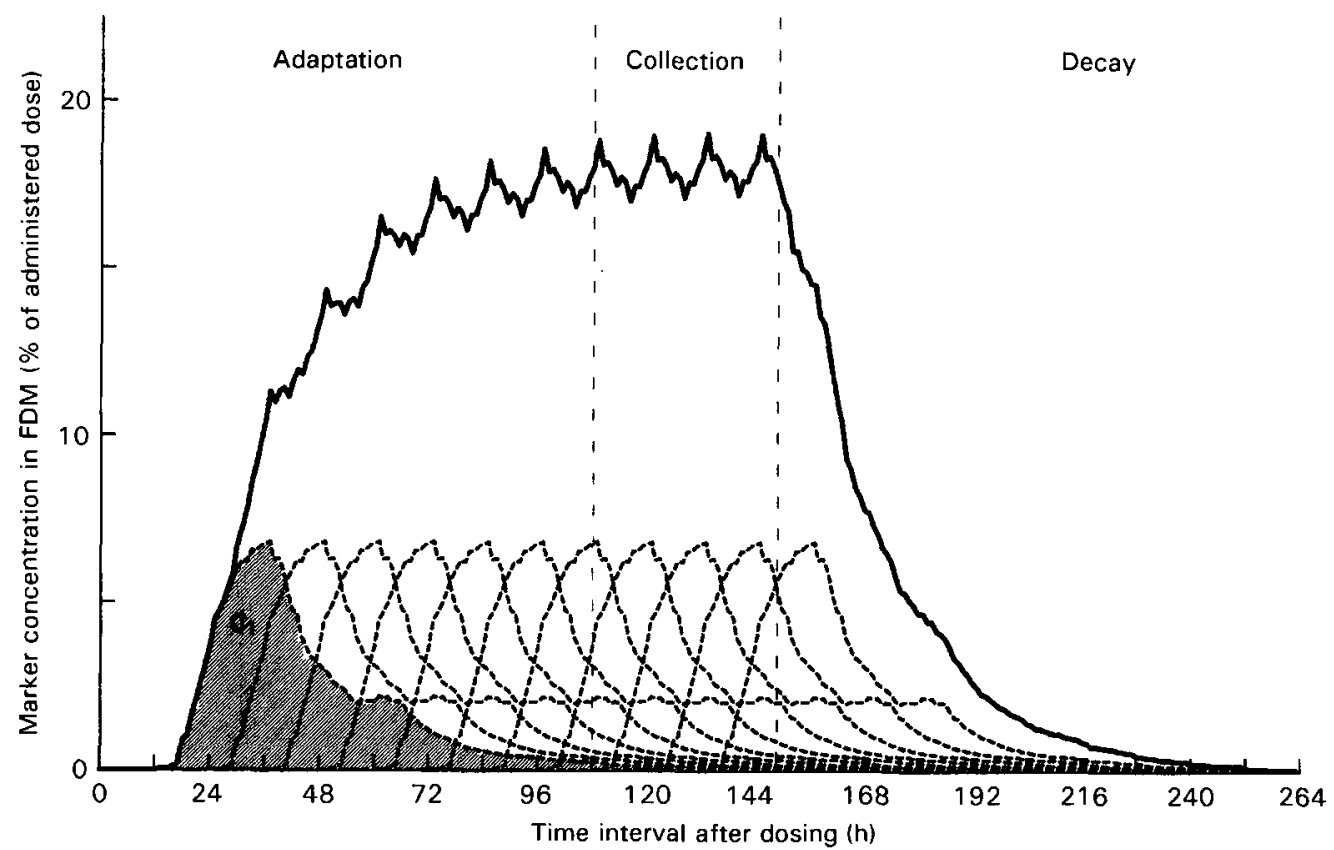

Fig. 1. Granulated polyamide marker concentration in individual grab-samples predicted for continuous dosing in Zebu cattle (Bos indicus). Adaptation period, collection and decay phase ( - ) are determined mathematically from marker excretion patterns following a single pulse dose application $\left(c_{1}\right.$, moving average of five animals), assuming $12 \mathrm{~h}$

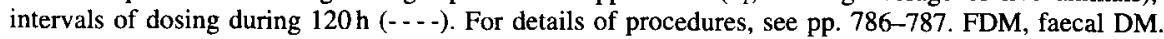

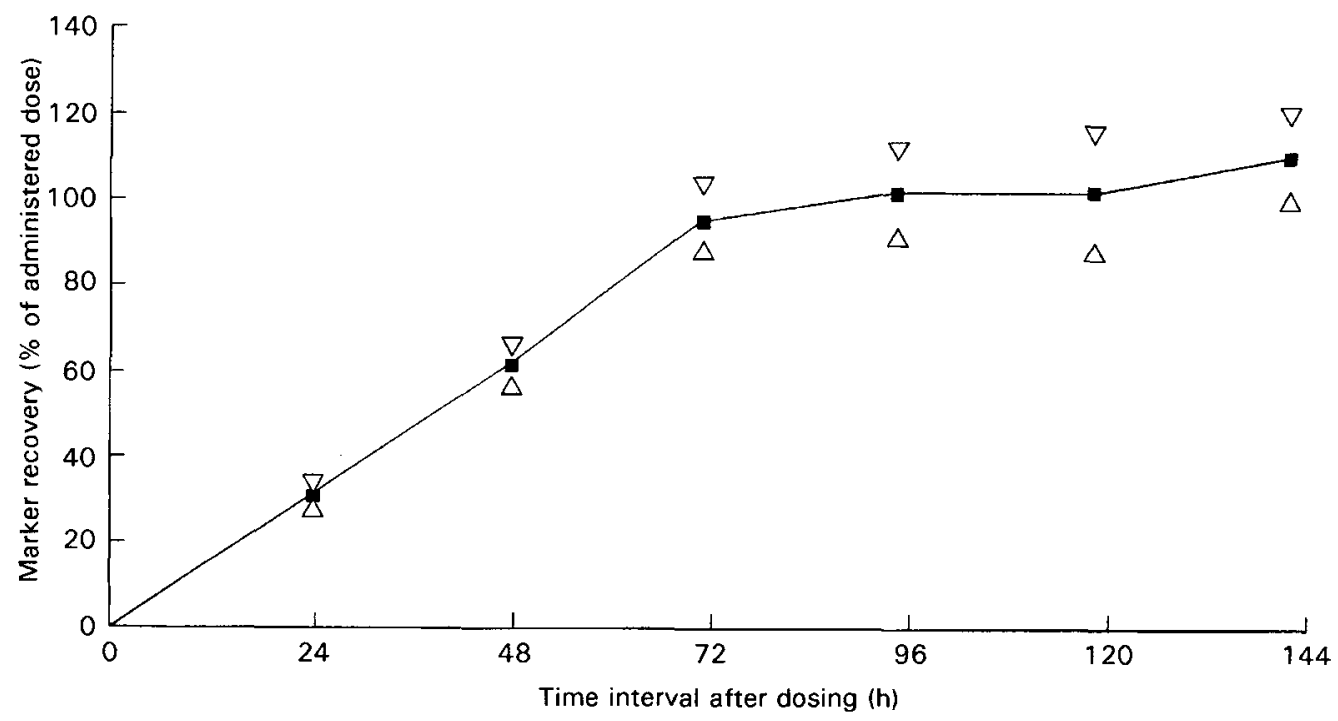

Fig. 2. Daily recovery of granulated polyamide (PA) marker in faeces of Zebu cattle (Bos indicus) following continuous dosing of $35 \mathrm{~g}$ PA at $12 \mathrm{~h}$ intervals. Values are means $(\boldsymbol{G})$ and standard deviations $(\triangle)$ for four animals. 
Table 4. Recovery of granulated polyamide marker in dry season field experiments with Zebu cattle (Bos indicus)

(Mean values with their standard errors)

\begin{tabular}{|c|c|c|c|c|c|}
\hline \multirow[b]{2}{*}{ Trial } & \multirow[b]{2}{*}{ Treatment* } & \multirow{2}{*}{$\begin{array}{l}\text { Sampling } \\
\text { technique }\end{array}$} & \multicolumn{3}{|c|}{ Marker recovery $(\%)$} \\
\hline & & & Mean & SE & $n$ \\
\hline \multirow[t]{2}{*}{$\mathbf{F} 1$} & $\mathbf{P}$ & Aliquots & 93.7 & 1.49 & 3 \\
\hline & PS & Aliquots & 97.3 & 3.72 & 4 \\
\hline \multirow[t]{2}{*}{$\mathrm{F} 2$} & $\mathbf{P}$ & gs $-10 h$ & $104 \cdot 2$ & 4.05 & 3 \\
\hline & PS & $\mathrm{gs}-10 \mathrm{~h}$ & $97 \cdot 1$ & $4 \cdot 22$ & 4 \\
\hline F3 & PS & Aliquots & $95 \cdot 3$ & 1.56 & 3 \\
\hline F4 & PS & $g s-5 h$ & $98 \cdot 1$ & $2 \cdot 84$ & 4 \\
\hline Mean & & & 97.6 & 1.52 & 21 \\
\hline
\end{tabular}

P, pasture; PS, pasture and supplement; Aliquots, aliquot sub-sampling from $24 \mathrm{~h}$ pools of faeces; gs - $10 \mathrm{~h}$, grabsampling every $10 \mathrm{~h}$; gs $-5 \mathrm{~h}$, grab-sampling every $5 \mathrm{~h}$.

* For details, see p. 787.

the $5 \mathrm{~h}$ sampling interval as well as for the two intermittent $10 \mathrm{~h}$ intervals. The standard error of the relative divergence between estimated FDM and actual excretion calculated for the $5 \mathrm{~h}$ interval was 2.84 as compared with values of 5.11 and 3.44 determined for the two $10 \mathrm{~h}$ intervals. To obtain about twenty-four faecal samples within measurement periods of $7-10 \mathrm{~d}$, an interval of $7 \mathrm{~h}$ was adopted for the collection of grab-samples in trials $\mathrm{C} 3, \mathrm{C} 4$, and $\mathrm{C} 5$.

The influence of type of feed, amount of feed ingested and supplement treatment on the recovery of PA marker as determined in trials C1-C5 is illustrated in Table 5. As in the

Table 5. Influence of forage quality, feeding level and supplementation on recovery of granulated polyamide marker as determined in indoor experiments with Zebu cattle (Bos indicus)

(Mean values with their standard errors)

\begin{tabular}{|c|c|c|c|c|c|c|}
\hline \multirow[b]{2}{*}{ Trial } & \multirow[b]{2}{*}{ Basic feed } & \multirow[b]{2}{*}{ Supplement } & \multirow[b]{2}{*}{ Feeding level } & \multicolumn{3}{|c|}{ Marker recovery $(\%)^{*}$} \\
\hline & & & & Mean & $\mathrm{SE}$ & $n$ \\
\hline $\mathrm{Cl}$ & Rice straw & Cowpea hay & LS & $93 \cdot 7^{a}$ & $1 \cdot 12$ & 6 \\
\hline $\mathrm{C} 2$ & $\begin{array}{l}\text { Rice straw } \\
\text { Rice straw }\end{array}$ & Cowpea hay & $\begin{array}{l}\mathrm{L} \\
\mathrm{MS}\end{array}$ & $\begin{array}{l}57 \cdot 2^{\mathrm{d}} \\
94.8^{\mathrm{a}}\end{array}$ & $\begin{array}{l}4.66 \\
1.95\end{array}$ & $\begin{array}{l}6 \\
6\end{array}$ \\
\hline C3 & $\begin{array}{l}\text { Bush hay } \\
\text { Bush hay } \\
\text { Bush hay } \\
\text { Bush hay }\end{array}$ & $\begin{array}{l}\text { Rice feed meal } \\
\text { Rice feed meal }\end{array}$ & $\begin{array}{l}\text { L } \\
\text { M } \\
\text { LS } \\
\text { MS }\end{array}$ & $\begin{array}{c}72 \cdot 9^{\mathrm{cd}} \\
79 \cdot 2^{\mathrm{c}} \\
91 \cdot 3^{\mathrm{a}} \\
102 \cdot 2^{\mathrm{ab}}\end{array}$ & $\begin{array}{l}3.48 \\
2.40 \\
2 \cdot 36 \\
0.52\end{array}$ & $\begin{array}{l}3 \\
3 \\
3 \\
3\end{array}$ \\
\hline $\mathrm{C} 4$ & $\begin{array}{l}\text { Green pasture vegetation } \\
\text { Green pasture vegetation } \\
\text { Green pasture vegetation } \\
\text { Green pasture vegetation }\end{array}$ & $\begin{array}{l}\text { Rice feed meal } \\
\text { Rice feed meal }\end{array}$ & $\begin{array}{l}\text { L } \\
\text { H } \\
\text { LS } \\
\text { HS }\end{array}$ & $\begin{array}{r}98 \cdot 8^{\mathrm{ab}} \\
100 \cdot 4^{\mathrm{ab}} \\
97 \cdot 5^{\mathrm{ab}} \\
110 \cdot 0^{\mathrm{b}}\end{array}$ & $\begin{array}{l}4 \cdot 12 \\
5 \cdot 48 \\
2 \cdot 71 \\
3 \cdot 58\end{array}$ & $\begin{array}{l}3 \\
3 \\
3 \\
3\end{array}$ \\
\hline $\mathrm{C} 5$ & $\begin{array}{l}\text { Green pasture vegetation } \\
\text { Green pasture vegetation } \\
\text { Green pasture vegetation } \\
\text { Green pasture vegetation }\end{array}$ & $\begin{array}{l}\text { Rice feed meal } \\
\text { Rice feed meal }\end{array}$ & $\begin{array}{l}\mathrm{L} \\
\mathrm{H} \\
\mathrm{LS} \\
\mathrm{HS}\end{array}$ & $\begin{array}{r}97 \cdot 8^{\mathrm{ab}} \\
98 \cdot 4^{\mathrm{ab}} \\
100 \cdot 2^{\mathrm{ab}} \\
102 \cdot 6^{\mathrm{ab}}\end{array}$ & $\begin{array}{l}4-24 \\
0-39 \\
6-15 \\
2 \cdot 36\end{array}$ & $\begin{array}{l}3 \\
2 \\
3 \\
3\end{array}$ \\
\hline
\end{tabular}

a.b,c,d Mean values with different superscript letters were significantly different $(P \leq 0.05)$.

$\mathrm{L}$, low (maintenance); $\mathrm{M}$, medium $(1.3 \times$ maintenance); $\mathrm{H}$, high $(1.6 \times$ maintenance); $\mathrm{S}$, supplement.

* Marker recovery determined from aliquot sub-samples $(\mathrm{C} 1, \mathrm{C} 2)$ or from grab-samples taken every $7 \mathrm{~h}(\mathrm{C} 3, \mathrm{C4}, \mathrm{C} 5)$. 
field trials, differences in marker recovery due to the method of faecal collection (aliquot sub-sampling from a $24 \mathrm{~h}$ pool or grab-sampling at $7 \mathrm{~h}$ intervals) were not statistically significant. Of a total of 1027 grab-samples collected in trials C3, C4 and C5, only twentynine samples were excluded according to the criteria mentioned previously. Among the eighteen samples weighing less than $10 \mathrm{~g} \mathrm{DM}$, four contained no PA particles and nine samples showed very high PA concentrations. Of the remaining eleven samples that were excluded, only one was without marker, while the others contained extremely high amounts of PA. Five of these samples had a dry mass of 50-100 g and two samples weighed more than $100 \mathrm{~g}$.

Statistical analyses showed that for diets based on green feed neither the quantity ingested nor the supplement treatment had a measurable influence on marker recovery $(P>0.05)$; thus interactions between diet components could be excluded. For diets based on bush hay or rice straw (straw diets), more feed was ingested by supplemented compared with unsupplemented animals (trials $\mathrm{C} 2, \mathrm{C} 3, P \leq 0.001$ ), so that it was not possible to isolate the impact of food intake and supplement treatment. Marker recovery determined for unsupplemented straw diets (trials C2, C3; treatments L, M) averaged 66.6 (SE 3.78) \% ( $n$ 12), whereas for supplemented straw diets (trials C1 and C2, C3; treatments LS, MS) marker recovery amounted to 95.1 (SE 1.17) \% ( $n 18)$, with the difference being significant at $P \leq 0.001$.

Excluding data obtained for unsupplemented straw diets, the overall average recovery of marker from field and indoor trials was 98.1 (SE 0.93 ) \% ( $n$ 62). For supplemented straw diets as well as for supplemented and unsupplemented diets of green feed, a linear relationship was established between the excreted FDM and the amount of faeces estimated from the recovered amount of PA marker in faecal samples (Fig. 3). FDM estimated from marker concentration in faeces was correlated with the actual excretion $(r 0.98, n 62$; $P \leq 0.001)$. Using PA marker overestimated the actual excretion by $2.4 \%$ on average.

\section{Sampling procedures}

In trial C5, PA concentrations were determined in grab-samples taken at $7 \mathrm{~h}$ intervals and in all defaecations occurring between 07.00 and 18.00 hours during ten consecutive days, which enabled diurnal patterns of marker excretion to be studied. To compare PA excretion among the eleven animals, the marker concentration in individual samples obtained for a particular animal was divided by the average PA concentration of all grab-samples collected for that animal during the trial (standardized marker concentration). Visual inspection of the plotted data indicated a regular accumulation of high marker concentrations between 08.00 and 18.00 hours, whereas low marker concentrations were more equally distributed throughout the $24 \mathrm{~h}$ day. To test for the existence of a cyclical variation in standardized PA concentration over time, each of the eleven data sets was fitted to a sine wave function. In all cases, $r$ for the function was below 0.21 , and for eight animals $r<0.06$. The irregular patterns of PA excretion over time despite fixed hours of marker application and feed distribution could explain why average PA recovery was less than $50 \%$ for unsupplemented animals and less than $80 \%$ for supplemented cattle when samples were taken during three fixed intervals of $2 \mathrm{~h}$ in the morning, at 12.00 hours and in the evening (F1).

Data obtained from grab-samples collected in trials C3, C4 and C5 were compiled after standardizing marker concentration as described previously. Comparing the PA concentration in grab-samples collected during the day (07.00-18.00 hours; maximum fifteen samples per animal and experiment) and the night (19.00-06.00 hours; maximum 


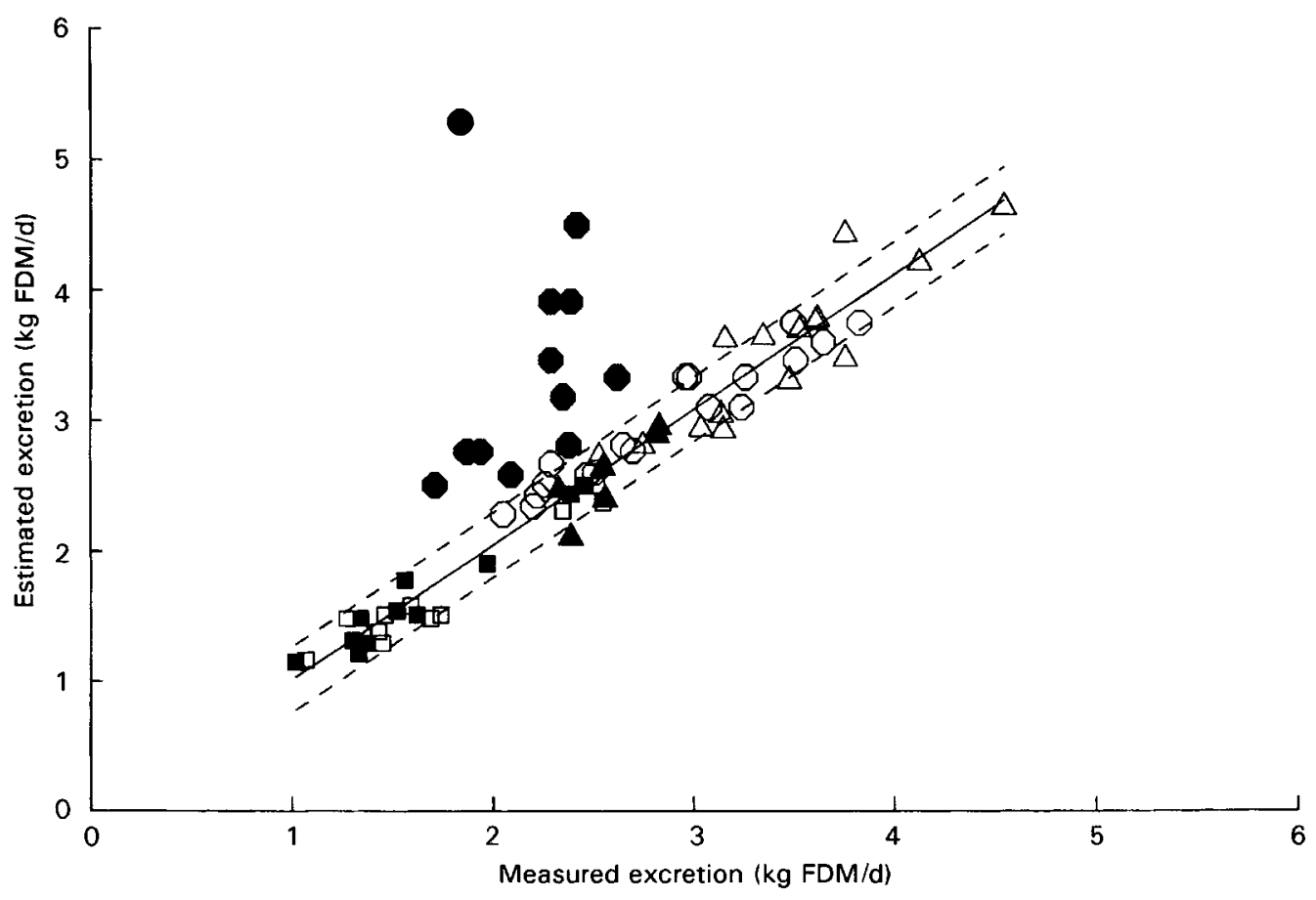

Fig. 3. Relationship between measured faecal excretion and faecal excretion estimated from the application of granulated polyamide marker as determined for unsupplemented and supplemented diets of straw $(\Theta, O)$, green pasture vegetation $(\boldsymbol{G}, \square)$ and unsupplemented and supplemented diets selected on natural pasture during the dry season $(\boldsymbol{\Lambda}, \triangle)$ for Zebu cattle (Bos indicus). Values obtained for unsupplemented straw diets were omitted from the calculation of the regression line (-) and its $95 \% \mathrm{Cl}(---)$. For details of diets and procedures see Tables 2 and 3 and pp. 786-792. FDM, faecal DM. $y=-0.03+1.04 x, r^{2} 0.96, n 62$.

thirteen samples per animal and experiment), the standardized marker concentration was 1.03 (SE $0.018 ; n 541$ ), and 0.96 (SE $0.023 ; n 486$ ) of the $24 \mathrm{~h}$ average respectively with the difference in marker concentration between the day and night grab-samples being significant at $P \leq 0.001$. At the same time, the mass of grab-samples collected during the night was on average $10.8 \%$ higher than the mass of samples collected during the day, i.e. 97.0 (SE 2.52) g DM; ( $n$ 486) v. 87.6 (SE 2.13) g DM ( $n$ 541; $P \leq 0.001)$. The correlation between log-transformed sample mass of the day and night grab-samples and their standardized PA concentration was determined at $r-0.46(n 1027 ; P \leq 0.001)$. Due to the tendencies for higher PA concentrations in smaller grab-samples and lower sample masses during the day, marker recovery determined for individual animals from grab-samples collected during the day (trials C4, C5, and C3 treatments LS, MS) was 104.9 (SE 2.32) \% ( $n$ 29) compared with a recovery of 93.8 (SE 2.02) \% ( $n$ 29) calculated for the night values. Faecal excretion estimated from either the day or night PA concentrations (absolute values) was correlated with the measured excretion ( $24 \mathrm{~h}$ average), giving $r 0.95$ ( $n 29 ; P \leq 0.001$ ) for both sampling periods. FDM estimated from day and night values respectively was on average 96.8 (SE 2.22) \% ( $n$ 29) and 108.0 (SE 2.30) \% ( $n$ 29) of the actual excretion. In trial C5, where all defaecations occurring during the day were analysed for marker concentration, forty to fifty day samples were obtained for each animal during the $10 \mathrm{~d}$ measurement period. FDM estimated from their average marker concentration was correlated with the actual faecal excretion $(r 0.98, n 11 ; P \leq 0.001)$. Estimated FDM was 
on average 97.9 (SE 3.00) \% ( $n$ 11) of the actual excretion, thus the precision for the estimation of FDM from average PA concentration in up to fifty day samples was not significantly different from estimates based on the average of a maximum of fifteen day samples that were obtained applying the regular $7 \mathrm{~h}$ grab-sampling schedule.

To test whether pooling of grab-samples can replace the analysis of single samples, the marker quantities (g PA) determined in individual grab-samples collected for a particular animal and experiment were summed up and then divided by the sum of the masses of all samples (kg FDM), using data from experiments $\mathrm{C} 3, \mathrm{C} 4$ and $\mathrm{C} 5$ but excluding values obtained for unsupplemented straw diets (trial C3; treatments L, M). FDM estimated from marker concentration in mathematically pooled grab-samples was correlated with the actual excretion $(r 0.97, n 29 ; P \leq 0.001)$.

\section{DISCUSSION}

\section{Marker adminstration}

The oral administration of the PA marker using gelatine capsules is achieved without difficulty or harmful effects on cattle. With a correct positioning of the applicator the capsule is swallowed unchewed. To avoid loss of particles through regurgitation of the capsule, animals should be offered small amounts of feed or should be allowed to graze immediately after marker administration. Furthermore, the distinct rumen contractions accompanying feed intake will lead to a thorough mixing of PA particles with rumen contents and ensure their regular passage through the rumen-omasal orifice (Pond et al. 1989).

\section{Gastrointestinal marker passage}

Peak concentration of PA marker in faeces was reached between 23.0 and $34.6 \mathrm{~h}$ after a single oral pulse dose application. This is similar to the result obtained by Des Bordes \& Welch (1984) using plastic particles of the same specific gravity. The quantitative recovery of the amount of PA administered about $6 \mathrm{~d}$ after pulse dose application demonstrates that marker administration and analysis of faecal samples can be carried out without particle losses. Complete recovery of the marker also indicates quick and thorough marker passage through the gastrointestinal tract, which would be expected from rumen kinetics and passage rates described for small plastic particles with a specific gravity of 1.1-1.2 (King \& Moore, 1957; Campling \& Freer, 1962; Des Bordes \& Welch, 1984; Lechner-Doll \& von Engelhardt, 1989; Kaske et al. 1989; Welch, 1990). According to Katoh et al. (1988) and Welch (1990) the low proportion of particles with teethprints (i.e. ruminated particles) indicates a short rumen retention time of the marker. Administration of PA at regular intervals of $12 \mathrm{~h}$ leads to a plateau concentration of marker in faeces on the fourth day after the start of the marker application. The period of pre-experimental marker dosing is thus shorter for PA than for powdered polyethylene, where the plateau value is reached after 310 d (Chandler et al. 1966; Baran \& Boda, 1982), while continuous intraruminal release of $\mathrm{Cr}_{2} \mathrm{O}_{3}$ leads to plateau concentrations in faeces at 5-6 d after the start of dosing (Laby et al. 1984).

\section{Marker recovery}

In the field, $97.6 \%$ of administered PA was recovered in faeces and the correlation $(r 0.94$, $n 21 ; P \leq 0.001$ ) between the actual faecal excretion and the values estimated from faecal 
PA concentrations demonstrates the marker's suitability for studies carried out in extensively-managed grazing systems. In the indoor experiments, the recovery of PA averaged 98.3 (SE 1.18) \% $(n$ 41) for diets based on green-pasture vegetation and supplemented straw diets. The recovery of $98.1 \%$, which was determined as an overall average for indoor and field experiments with a $\mathrm{CV}$ of $7.51 \%$, indicates that the recovery of PA is less dependent on experimental circumstances than the recoveries of $\mathrm{Cr}_{2} \mathrm{O}_{3}$ and $\mathrm{Yb}$, which are reported to vary in the range 75-117\% and 93-125\% respectively (Brisson et al. 1957; Corbett et al. 1958; Knapka et al. 1967; Hatfield et al. 1990). However, when cattle consumed unsupplemented straw diets, PA recovery varied from 34.4 to $84.4 \%$, leading to an overestimation of the actual faecal excretion by 18-187\%. Although with these diets the daily excretion of PA reached equilibrium about 5-9 d after the start of marker dosing, the plateau values were low and relatively inconsistent. Similar observations were reported by Murphy et al. (1989) for cattle on a low-N diet. To determine the factors influencing PA recovery, a multiple linear regression analysis was carried out on seventy-four data sets (trials F1-F4, C1-C5) combining organic matter intake (related to metabolic body mass), in vivo organic matter digestibility and $\mathrm{N}$ content of the diet. While digestibility did not attain a significance level of $15 \%$ and was excluded from the model, $68.8 \%(P \leq 0.001)$ and $25.1 \%(P \leq 0.01)$ of the variation in PA recovery was explained by the $\mathrm{N}$ content and the intake of organic matter respectively, the two variables being correlated $(r 0.21)$. The $\mathrm{N}$ content of unsupplemented straw diets averaged $5.7 \mathrm{~g} \mathrm{~N} / \mathrm{kg}$ OM compared with $\mathrm{N}$ contents of $12-17 \mathrm{~g} / \mathrm{kg}$ OM in supplemented straw diets (C1, C2 treatment MS, C3 treatments LS, MS), diets that were selected from pasture during the dry season (F1-F4) and diets based on green pasture vegetation (C4, C5). The correlation ( $r 0.84)$ between $\mathrm{N}$ content and PA recovery supports the conclusion that the poor performance of the marker with unsupplemented straw diets may be caused by a low $\mathrm{N}$ content in the diet. This observation is congruous with the results of Murphy et al. (1989). They gave a single pulse dose of small plastic particles of a specific gravity of $1 \cdot 10$ and 1.34 to two cattle fed on a ration of rice straw $(950 \mathrm{~g} / \mathrm{kg})$ and Leucaena leaf $(50 \mathrm{~g} / \mathrm{kg} ; \mathrm{N}$ content $6.1 \mathrm{~g} / \mathrm{kg} \mathrm{DM}$ ) and recovered 79.9 and $80.1 \%$ of the marker after $12 \mathrm{~d}$. The incomplete marker recovery might be explained by a delayed rate of particulate passage due to slow microbial breakdown of the ingesta caused by sub-optimal rumen $\mathrm{NH}_{3}$ concentrations (Moran et al. 1983; Oosting \& Waanders, 1993). Incomplete particle recovery has been ascribed also to the properties of the rumen mat, the relative rumen fill and rumen ingesta consistency (Welch, 1990). Particles with higher density than the rumen mat have a better chance of sedimenting into the lower region of the reticulum, from where the probability of passing the reticulo-rumen omasal orifice is highest (Lechner-Doll \& von Engelhardt, 1989). Reviewing literature, Murphy \& Kennedy (1993) pointed out that the characteristics of buoyancy and entanglement of particles which determine their sequestration in the rumen mat are quite variable. The extent to which the mat hinders particulate passage from the rumen depends on its density and on the relationship between concentrations of particles in the rumen mat and the ventral sac of the rumen. As losses of marker particles through regurgitation and rumination could be excluded for the present study, it is assumed that with feeds of low $\mathrm{N}$ content the PA particles accumulate in the rumen.

To determine the minimum $\mathrm{N}$ content $(N ; \mathrm{g} / \mathrm{kg} \mathrm{OM})$ required to obtain high PA recoveries $(R ; \%)$, a non-linear segmented regression consisting of two linear sections with one common point was fitted to the seventy-four observations. The line representing the equation for the lower section $(R=19 \cdot 632+8 \cdot 185 N)$ and the line described by the equation for the higher section $(R=91.028+0.473 N)$ intersected at $N 9.26 \mathrm{~g} / \mathrm{kg} \mathrm{OM}$ and $R$ 
$95.4 \%$. With respect to the applicability of PA marker under field conditions, this result indicates that reliable estimates of FDM can be expected where heterogeneous botanical composition of pastures enables cattle to select a diet containing more than $9.26 \mathrm{~g} \mathrm{~N} / \mathrm{kg}$ OM. In the present study, the field trials were carried out at the end of the dry season when the vegetation of Sahelian rangeland is of very poor quality (Le Houérou, 1980), but even then unsupplemented cattle were able to select a diet with a $\mathrm{N}$ content above the required minimum value. However, on semi-arid pastures with reduced species diversity or in systems where cattle graze exclusively on cereal stover for several months during the dry season (e.g. Dicko et al. 1983; Powell \& Mohamed-Saleem, 1987), the PA marker must be applied with caution.

\section{Sampling techniques}

A strongly varying and incomplete recovery of PA was obtained when faecal samples were taken at one to three fixed time intervals during the day. Similar problems have been experienced with $\mathrm{Cr}_{2} \mathrm{O}_{3}$ (Raymond \& Minson, 1955; Putnam et al. 1958; Hayes et al. 1964; Kiesling et al. 1969; Rittenhouse et al. 1970; Whittington et al. 1978) and Yb (Hatfield et al. 1990). However the correlation ( $r$ 0.95) between the actual excretion and the FDM estimated from the average PA concentration in grab-samples collected during either the day or night indicates that limiting the collection period to 11 or $13 \mathrm{~h}$ instead of $24 \mathrm{~h}$ also results in reliable FDM estimates, as long as sampling is equally distributed over the chosen time interval. If it is decided to limit faeces collection to either the day or the night, the marker recovery for the particular sampling period must be determined before routine measurements are carried out. Increasing the number of samples will improve the accuracy with which the average marker concentration occurring during the chosen time interval is determined. To avoid a negative impact on the grazing animal (Fisher et al. 1986; Hatfield et al. 1990) and to obtain sufficiently large samples, the interval between grab-sampling times should be at least $3-4 \mathrm{~h}$. Altogether, twenty to twenty-four grabsamples should be taken over 5-8 d. A longer collection period improves the precision with which average daily excretion is estimated, because variations between days in feed intake and faecal excretion are at least in part accounted for.

When grab-samples are collected during a $24 \mathrm{~h}$ period and analysed individually, marker recovery can exceed $100 \%$ (e.g. trial $\mathrm{C} 4$, treatment $\mathrm{HS}$ ). This is because average marker concentration is derived from the PA concentration in single grab-samples, whose marker concentration is weighted by the factor 1 . If several samples with high marker concentrations are obtained, average marker concentration and consequently marker recovery increase. This bias is largely reduced if the corrections described previously are applied, and in most cases only a few small samples will have to be excluded, which at the time often contain extremely high or low amounts of PA. The poor correlation between sample mass and marker concentration in individual grab-samples and the irregular variations in faecal PA concentrations throughout the day indicate that the amount of PA in contributory grab-samples is not proportional to the rate of faecal excretion at the time the sample was excreted. It might be possible, therefore, that pooling of grab-samples and subsampling mass aliquots from that pool leads to a more biased estimate of faecal excretion than calculations based on the unweighted mean of the PA concentration in individual grab-samples. If grab-samples are pooled, bias due to extreme PA concentrations in very small samples will not be significant because those concentrations are weighted by a small factor. Furthermore, this bias can be reduced if samples equivalent to less than $10 \mathrm{~g} \mathrm{DM}$ are not added to the pool. Pooling of grab-samples may however lead to erroneous estimates if 
extreme marker concentrations occur in heavy samples. This bias decreases when the total mass of the pool increases, i.e. when a sufficient number of grab-samples is available. The close correlation between FDM estimates from mathematically pooled samples and the actual excretion that was found in the present study indicates that reliable estimates of faecal output can be obtained from the PA concentration determined in pooled grabsamples. A thorough homogenization of the pooled samples is a prerequisite for correct marker determination in aliquot sub-samples. Good results were obtained when pooled faeces were diluted with water to a moisture content of $820-880 \mathrm{~g} / \mathrm{kg}$. To reduce analytical errors, it seems appropriate to sub-sample in total six to eight aliquots with an air-dry mass of approximately $200-250 \mathrm{~g}$.

\section{Assessment of optimal marker dose rate}

Results showed that marker recovery is independent of the quantity of feed ingested and of the quantity of marker administered. As model calculations illustrate (Fig. 4), a linear increase in PA concentration in faeces is accompanied by an exponential decrease in the extent to which faecal output is under- or overestimated due to analytical errors. On the basis of this correlation, the quantity of PA to be administered daily can easily be calculated for a particular experiment. Marker dose will depend on the required accuracy of FDM estimates and the feed intake and diet digestibility expected for individuals or a group of cattle. For example, if one decides to accept an overestimation of actual FDM by $5 \%$ and expects that losses of PA due to analytical problems will not exceed $1 \mathrm{~g}$ PA/kg FDM, an average marker concentration in faeces of $24 \mathrm{~g}$ PA $/ \mathrm{kg}$ FDM should be obtained. For animals consuming about $5 \mathrm{~kg}$ DM/d with a digestibility of $46 \%$, the marker dose would then be $65 \mathrm{~g}$ PA/d, whereas for animals consuming the same amount of feed with a digestibility of $68 \%$, only $39 \mathrm{~g}$ PA/d would have to be administered.

\section{Conclusions}

The application of PA as an external marker is a simple and precise method for the indirect quantification of faecal excretion of cattle and appears to be particularly suited for intake studies in extensive grazing systems. The short pre-experimental period of continuous dosing reduces costs and labour required for marker application and increases the practicability of the method under field conditions. Irrespective of the quantity of feed ingested, under- or overestimation of faecal excretion can be excluded if the botanical composition of the pasture is such that the $N$ content of the diet is at least $9.26 \mathrm{~g} / \mathrm{kg} \mathrm{OM}$. Instead of taking rectal grab-samples every $7 \mathrm{~h}$ during seven consecutive days, limitation of the grab-sampling period to approximately $12 \mathrm{~h}$ during the $24 \mathrm{~h}$ day is possible, but marker recovery must then be established for the particular experimental circumstances (diurnal rhythm of feed intake, timing of marker application, duration of the grab-sampling period) before routine measurements are carried out. Irrespective of the sampling schedule adopted, the period of grab-sampling should last 5-8 d and at least twenty to twenty-four samples should be collected. The laborious analysis of marker concentration in individual grab-samples can be replaced by pooling the samples and sub-sampling mass aliquots from that pool.

The authors would like to thank Deutsche Forschungsgemeinschaft (DFG) for funding this project. E. S. is grateful for the scholarships provided by Deutscher Akademischer Austauschdienst (DAAD) and Studienstiftung des Deutschen Volkes. 


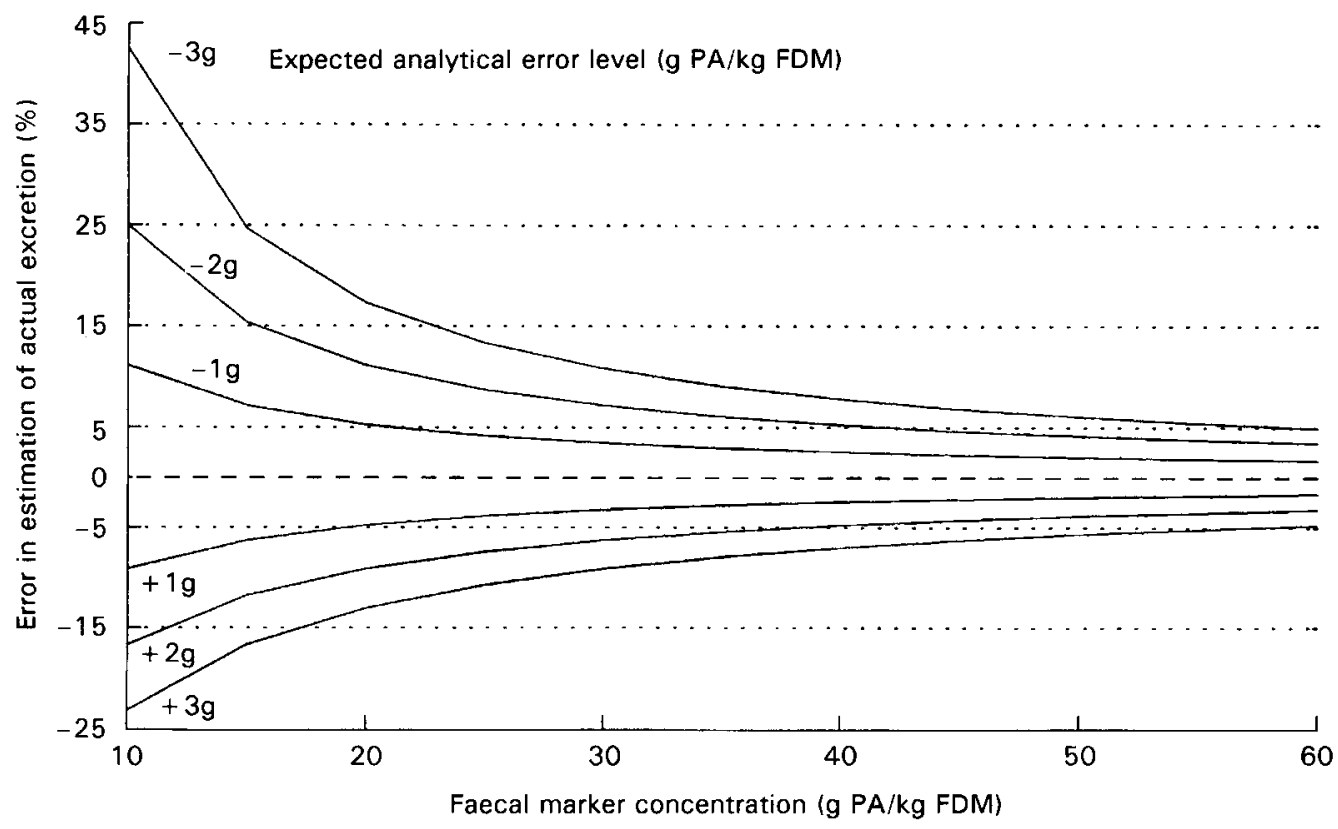

Fig. 4. Granulated polyamide (PA) marker concentration required in faeces (g PA/kg faecal DM (FDM)) of Zebu cattle (Bos indicus) to estimate total FDM excretion with an accepted level of accuracy, taking into account the error expected for the determination of marker concentration in faecal grab-samples $( \pm 1 \mathrm{~g} \sim \pm 3 \mathrm{~g} \mathrm{PA} / \mathrm{kg}$ FDM) due to analytical problems. For details of procedures, see pp. 786-792.

\section{REFERENCES}

Agricultural Research Council (1980). The Nutrient Requirements of Ruminant Livestock. Farnham Royal: Commonwealth Agricultural Bureaux.

Baran, M. \& Boda, K. (1982). Die Brauchbarkeit von Polyäthylen für Geschwindigkeitsmessungen der Futterpassage durch den Verdauungstrakt der Wiederkäuer (The usefulness of polyethylene for rate of passage measurements of feeds through the digestive tract of ruminants). Archiv für Tierernährung 32, 199207.

Brisson, G. J., Pidgen, W. J. \& Sylvestre, P. E. (1957). Effect of frequency of administration of $\mathrm{Cr}_{2} \mathrm{O}_{3}$ on its faecal excretion patterns by grazing cattle. Canadian Journal of Animal Science 7, 90-94.

Campling, R. C. \& Freer, M. (1962). The effect of specific gravity and size on the mean time of retention of inert plastic particles in the alimentary tract of the cow. British Journal of Nutrition 16, 507-518.

Chandler, P. T., Kesler, E. M. \& Jones, G. M. (1966). Excretion of polyethylene by dairy calves. Joumal of Animal Science 25, 64-68.

Cochran, R. C., Adams, D. C., Wallace, J. D. \& Galyean, M. L. (1986). Predicting digestibility of different diets with internal markers: evaluation of four potential markers. Journal of Animal Science 63, 1476-1483.

Cochran, R. C., Vanzant, E. S. \& Del Curto, T. (1988). Evaluation of internal markers isolated by alkaline hydrogen peroxide incubation and acid detergent lignin extraction. Journal of Animal Science 66, 3245-3251.

Corbett, J. L., Greenhalgh, J. D. F., Gwynn, P. E. \& Walker D. (1958). Excretion of chromium sesquioxide and polyethyleneglycol by dairy cows. British Journal of Nutrition 12, 266-275.

Cordova, F. J., Wallace, D. J. \& Pieper, R. D. (1978). Forage intake by grazing livestock: a review. Journal of Range Management 31, 430-438.

Des Bordes, C. K. \& Welch, J. G. (1984). Influence of specific gravity on rumination and passage of indigestible particles. Journal of Animal Science 59, 470-475.

Dicko, M. S., Lambourne, J., de Leeuw, P. N. \& de Haan, C. (1983). Nutrition animale - les bovins (Animal nutrition - cattle). In Recherches sur les systèmes des zones arides du Mali: résultats préliminaires. Rapport de Recherche no 5 (Research of Systems in the Arid Zones of Mali: Preliminary Results. Research Report no 5), pp. 95-96 [R. T. Wilson, P. N. de Leeuw and C. de Haan, editors]. Addis Ababa, Ethiopia: International Livestock Centre for Africa. 
Dicko-Touré, M. S. (1980). Measuring the secondary production of pasture: an applied example in the study of extensive production systems in Mali. In Browse in Africa. The Current State of Knowledge, pp. 245-251 [H. N. Le Houérou, editor]. Addis Ababa, Ethiopia: International Livestock Centre for Africa.

Fisher, D. S., Burns, J. C. \& Pond, K. R. (1986). Sampling effects on grazing behaviour in marked forage trials. Agronomy Abstracts p. 141.

Harniss, R. O., Price, D. A. \& Tomlin, D. C. (1975). Number of fistula samples needed for determination of sheep diet on sagebrush-grass range. Journal of Range Management 28, 417-419.

Hatfield, P. G., Clanton, D. C., Sanson, D. W. \& Eskridge, K. M. (1990). Methods of administering ytterbium for estimation of faecal output. Journal of Range Management 43, 316-320.

Hayes, B. W., Little, C. O. \& Mitchell, G. E. (1964). Influence of ruminal, abomasal and intestinal fistulation on digestion in steers. Journal of Animal Science 23, 764-766.

Holechek, J. L., Vavra, M. \& Pieper, R. D. (1982). Methods for determining the nutritive quality of range ruminant diets: a review. Journal of Animal Science 54, 364-375.

Kaske, M., Hatipoglu, S. \& von Engelhardt, W. (1989). Rumination of particles of different size and densities in sheep. Acta Veterinaria Scandinavica 86, 53-54.

Katoh, K., Sato, F., Yamazaki, A. \& Tsuda, T. (1988). Passage of indigestible particles of various specific gravities in sheep and goats. British Journal of Nutrition 60, 683-687.

Kiesling, H. E., Barry, H. A., Nelson, A. B. \& Herbel, C. H. (1969). Recovery of chromic oxide administered in paper to grazing steers. Journal of Animal Science 29, 361-364.

King, K. W. \& Moore, W. E. C. (1957). Density and size as factors affecting rate of passage of ingesta in the bovine and human digestive tracts. Journal of Dairy Science 40, 528-536.

Knapka, J. J., Barth, K. M., Brown, D. G. \& Cragle, R. G. (1967). Evaluation of polyethylene, chromic oxide and Cerium ${ }^{144}$ as digestibility indicators in burros. Journal of Nutrition $92,79-85$.

Kotb, A. R. \& Luckey, D. T. (1972). Markers in nutrition. Nutrition Abstracts and Reviews 42, 813-845.

Laby, R. H., Graham, C. A., Edwards, S. R. \& Kautzner, B. (1984). A controlled release intraruminal device for the administration of faecal dry matter markers to the grazing ruminant. Canadian Journal of Animal Science 64 Suppl., 337-338.

Langlands, J. P. (1974). Techniques for estimating nutrient intake and its utilisation by the grazing ruminant. In Digestion and Metabolism in the Ruminant. Proceedings of the IVth Intermational Symposium on Ruminant Physiology, pp. 320-332 [J. W. McDonald and A. C. J. Warner, editors]. Armidale: University of New England Publishing Unit.

Lechner-Doll, M. \& von Engelhardt, W. (1989). Particle size and passage from the forestomach in camels compared to cattle and sheep fed a similar diet. Journal of Animal Physiology and Animal Nutrition 61, 120 128.

Le Houérou, H. N. (1980). Composition chimique et valeur nutritive des fourrages ligneux en Afrique tropicale occidentale (Chemical composition and nutritional value of browse forages in tropical West Africa). In Les fourrages ligneux en Afrique - état actuel des connaissances (Browse Forages in Africa - The State of Knowledge), [H. N. Le Houérou, editor]. Addis Ababa, Ethiopia: International Livestock Centre for Africa.

Littell, R. C., Freund, R. J. \& Spector, P. C. (1991). SAS System for Linear Models. 3rd ed. Cary, NC: SAS Institute Inc.

Little, D. A. (1972). The relation of the chemical composition of feed to that of the extruded bolus. Australian Journal of Experimental Agriculture and Animal Husbandry 12, 126-130.

Mayes, R. W., Dove, H., Chen, X. B. \& Guanda, J. A. (1995). Advances in the use of faecal and urinary markers for measuring diet composition, herbage intake and nutrient utilisation in herbivores. In Recent Developments in the Nutrition of Herbivores. Proceedings of the IVth International Symposium on the Nutrition of Herbivores, pp. 381-406 [M. Journet, E. Grenet, M.-H. Farce, M. Theriez and C. Demarquilly, editors] Paris: INRA Editions.

Menke, K. H., Raab, L., Salewski, A., Steingass, H., Fritz, D. \& Schneider, W. (1979). The estimation of the digestibility and metabolizable energy content of ruminant feeding stuffs from gas production when they are incubated with rumen liquor in vitro. Journal of Agricultural Science, Cambridge 93, 217-222.

Meuret, M., Bartiaux-Thill, N. \& Bourbouze, A. (1985). Evaluation de la consommation d'un troupeau de chèvres latières sur parcours forestier -méthode d'observation directe des coups de dents - Méthode du marqueur oxyde de chrome (Evaluation of feed intake of a herd of milking goats on woodland pasture method of direct observation of bites - method of chromic oxide marker). Annales de Zootechnie 34, 159-180.

Moran, J. B., Satoto, K. B. \& Dawson, J. E. (1983). The utilization of rice straw fed to Zebu cattle and Swamp buffalo as influenced by alkali treatment and Leucaena supplementation. Australian Journal of Agricultural Research 34, 73-84.

Murphy, M. R. \& Kennedy, P. M. (1993). Particle dynamics. In Quantitative Aspects of Ruminant Digestion and Metabolism, pp. 87-105 [J. M. Forbes and J. France, editors] Wallingford, Oxon: CAB INTERNATIONAL. 
Murphy, M. R., Kennedy, P. M. \& Welch, J. G. (1989). Passage and rumination of inert particles varying in size and specific gravity as determined from analysis of faecal appearance using multicompartment models. British Journal of Nutrition $62,481-492$.

Naumann, K., Bassler, R., Seibold, R. \& Barth, K. (1983). Methodenbuch Band III. Die chemische Untersuchung von Futtermitteln (Handbook of Methodology, vol. 3. The Chemical Analysis of Forages). Neudamm, Germany: Verlag J. Neumann.

Oosting, S. J. \& Waanders, A. (1993). The effect of rumen ammonia nitrogen concentration on intake and digestion of wheat straw by goats. Animal Feed Science and Technology 43, 31-40.

Pond, K. R., Ellis, W. C., Matis, J. H. \& Deswysen, A. G. (1989). Passage of chromium mordanted and rare earth-labelled fibre: time of dosing kinetics. Journal of Animal Science 67, 1020-1028.

Powell, J. M. \& Mohamed-Saleem, M. A. (1987). Nitrogen and phosphorus transfer in a crop-livestock system in West Africa. Agricultural Systems 25, 261-277.

Prigge, E. C., Stuthers, B. A. \& Jacquement, N. A. (1990). Influence of forage diets on ruminal particle size, passage of digesta, feed intake and digestibility by steers. Journal of Animal Science 68, 4352-4360.

Putnam, P. A., Loosli, J. K. \& Wamer, R. G. (1958). Excretion of chromium oxide by dairy cows. Journal of Dairy Science 41, 1723-1729.

Raymond, W. F. \& Minson, D. J. (1955). The use of chromic oxide for estimating the faecal production of grazing animals. Joumal of the British Grassland Society 10, 282-296.

Reid, J. T., Woolfolk, P. G., Hardison, W. A., Martin, C. M., Brundage, A. L. \& Kaufmann, R. W. (1952). A procedure for measuring the digestibility of pasture forage under grazing conditions. Journal of Nutrition 46, 255-269.

Rittenhouse, L. R., Clanton, D. C. \& Streeter, C. L. (1970). Intake and digestibility of winter range forage by cattle with and without supplements. Journal of Animal Science 31, 1221-1251.

Scales, G. H., Streeter, C. L., Denham, A. H. \& Ward, G. M. (1974). Effect of mastication, salivary contamination and leaching on the chemical composition of forage samples collected via esophageal fistulae. Journal of Animal Science 38, 1278-1283.

Statistical Analysis Systems (1989). SAS/STAT Users Guide, Version 6, 4th ed., vol. 2. Cary, NC: SAS Institute Inc.

Welch, J. G. (1990). Inert plastics as indicators of physiological processes in the gastrointestinal tract of ruminants. Journal of Animal Science 68, 2931-2935.

Whittington, D. L. \& Hansen, R. M. (1985). Oesophageal- and rumen-fistulated animals for range livestock research in remote areas. World Animal Review 56, 45-50.

Whittington, D. L., Turner, H. A. \& Raleigh, R. J. (1978). Evaluation of chromic oxide, lignin, crude fibre, nitrogen and indigestible dry matter as indicators to determine faecal production and forage intake. Proceedings of the American Society of Animal Science 29, 1-5. 